高分子論文集 (Kobunshi Ronbunshu), Vol. 48, No. 11, pp. 679-684 (Nov., 1991)

\title{
ポリオキシメチレンの物性に及ぼす圧延の効果
}

\author{
中山 和郎*1 ・海藤 彰*1
}

（受付 1991 年 4 月 6 日・蕃査終了 1991 年 4 月 19 日)

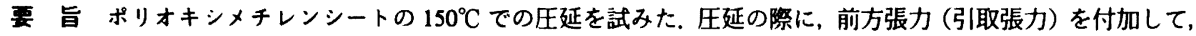
安定な压延を行うことができた，前方張力は圧下力や圧延倍率に影掣し，前方張力を高くすると，圧下力が低下し た. 圧延したシートの力学的性質と压延条件の関係を調べた. 压延倍率が高くなると、弾性率と引張強さが向上し た.さらに, 高圧延倍率ではシートの透明性が著しく向上した。
\end{abstract}

1 緒言

大変形付与による高弾性率を有する高分子材料の製造 が注目されており, 静水圧押出し (1), 2), 固体押出し ${ }^{3)}$, タ イ延伸“などによる延伸・配向の研究が行われてきた。 高分子フィルムやシートの延伸加工法としては, ロール や部分的な加熱装置を用いた方法についても多くの報告 がある.

このうちで, 結晶性高分子の圧延は分子鎖が配向した 構造を固体高分子に付与できる方法の一つである. 圧延 がシートの力学的性質などに及ばす効果については, ポ リプロピレンふ〜7, ポリエチレンクやポリオキシメチレ ン (POM $)^{8), 9)}$ を含めて, いくつかの結晶性高分子につい て示されている.

圧延のほかにロールを利用したシートの加工法がいく つかおり, 先に海藤らは高弾性率フィルムの加工法とし てロール引抜きを提案し, 高倍率の変形付与を可能にし た (10) 12). また, Burke らによって, ロール延伸法のポリ オレフィンへの適用が報告されている(3). さらに, Laughner らによってニップヒータ延伸法が試みられて (る ${ }^{14)}$.

以前より, 我々はポリプロピレンシートのシングルパ スヤマルチパスによる圧延 ${ }^{(5)}$, 16) や超高分子量ポリエチ レンの急冷圧延などの研究を行ってきた ${ }^{17)}$. こうした結 果を通して，比较的厚いシートに対しても配向の付与が 可能な方法の一つであることに注目してきた.ここで は, POM の力学的性質を改善するために, POM シート の圧延を試みた. 特に, 圧延の際の前方張力の付加が圧 延条件や圧延したシートの物性に及ぼす影響を詳しく調 ベた.

*1 維維高分子材料研究所（亚305つくば市東 1-1-4）

\section{2 実験方法}

\section{1 試料}

末延伸, 無配向の POM ホモポリマーのシート（テ ナック 5010, 旭化成工業(株)製) を使った. シートの厚 さが $1 \mathrm{~mm}$ の長尺シートで，幅を $100 \mathrm{~mm}$ にスリットし て圧延のための原反とした. 素材シートの示差走査熱量

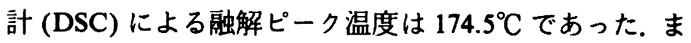
た, 密度から測定した結晶化度（重量平均）は 63.4\%で あった。

\section{2 圧延装置と圧延条件}

圧延中にシートに張力を付加できる圧延装置を用い て, 圧延を行った. Fig. 1 には, 圧延装置の概略図を示し た. 二段圧延機と巻出リール, 巻取リール, 予熱板とコ ントローラからなっており, 圧延荷重は最高 $20000 \mathrm{kgf}$, 前方張力は最高 $1000 \mathrm{~kg}$ まで加えることができる.

圧延ロールはSKD61 製で，直径 $100 \mathrm{~mm}$, 長さ 130 . $\mathrm{mm}$ である. ロールの中心部にはカートリッジヒーター を挿入して, 表面の温度を表面温度計で測定し, PID制 御により温度コントロールした.

POM シートを $160^{\circ} \mathrm{C}$ に加熱した予熱板の間を通し て， $150^{\circ} \mathrm{C}$ に加熱した一対の圧延ロールを用いて， ワン パスの圧延を行った. なお, 圧延の際に潤滑液は用いず,

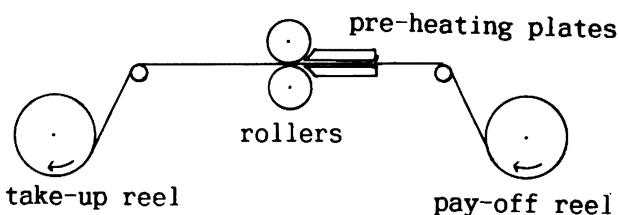

Fig. 1. Schematic drawing of rolling apparatus. 
無潤滑の圧延とした。

圧延の速度は比較的遅く， ロール周速 $31.4 \mathrm{~cm} / \mathrm{min}$ を 選んだ．巻取リールの回転数を調整して，圧延ロールを 出てきたシートに一定の前方張力または, 引取張力 $(\sigma)$ を付加した。 $\sigma$ はロールと巻取リールの中間に設置した ロードセルを用いて測定した。 $\sigma$ は条件 A では $65 \pm 5$ $\mathrm{kgf}$, 条件 Bでは $140 \pm 10 \mathrm{kgf}$ を選んだ。また, 圧延の際 の圧下力 $(F)$ は上ロールの軸受けの両端に取付けた二つ のロードセルにより測定した.

压延したシートの加工度のめやすとして, $h_{\mathrm{T}} / h_{1}$ 及び $h_{2} / h_{1}$ を比較した。 ここで， $h_{\mathrm{r}}$ はロール間隙， $h_{1}$ は原反 シートの厚さ， $h_{2}$ は圧延後の厚さである. また, 圧延倍 率 $\lambda$ を原反シートの長さ $\left(L_{1}\right)$ と圧延後の長さ $\left(L_{2}\right)$ 加ら 求めた。

$$
\lambda=L_{2} / L_{1}
$$

\section{3 測定}

圧延したシートの透明性を評価するために，柴外可視 分光光度計（(株)島津製作所製, MPS-2000）を使って, $550 \mathrm{~nm}$ での透過率を求めた。 熱的性質として，パーキン エルマーDSC-II 型による示差走査熱量曲線を $5^{\circ} \mathrm{C} / \mathrm{min}$ の昇温速度で測定し, 融解温度及び融解熱を求めた，温 度補正には，インジゥムを用いた。 シートの密度は，四 塩化炭素-n-ヘプタン系の密度勾配管を用いて， $25^{\circ} \mathrm{C} て ゙$ 測定した．圧延したシートの力学的性質の評価として, $23^{\circ} \mathrm{C}$ での応力ーひずみ曲線を測定し, 初期弾性率, 引張 強さ（破断強度），破断伸びの異方性を求めた，また，動 的粘弾性測定装置レオバイブロン DDV-III-EA（オリエ ンテック社製）を用い，3.5 110 Hz での動的弾性率の 温度変化の測定を行った。

圧延シートにおける微結晶の選択配向性を調べるため に, 広角 $\mathbf{X}$ 線回折極図形を作成した， $\mathbf{X}$ 線発生装置はリ ガク製ガイガーフレックスXGC-20を用い，Ni 万過し た Cu- $K_{a}$ 線を使った．回折強度はシンチレーションカウ ンタと波高分析器を用いて, 透過法 (Decker Asp \& Harker 法) と反射法（Shultz 法）を併用して測定した. 009 反射, 100 反射を用い,バックグラゥンド補正と吸収 補正を行い，極図形を描いた。

\section{3 結果と考察}

\section{1 圧延挙動}

圧延温度は $150^{\circ} \mathrm{C}$ で一定として, ロール間隙 $\left(h_{\mathrm{r}}\right)$ の設 定を変えて，また， 前方張力 $(\sigma)$ を条件 A では $65 \pm 5$ kgf, 条件 Bでは $140 \pm 10 \mathrm{kgf}$ の二段階に変えて圧延を 行った.なお，後方張力は特別には加えなかった．Fig. 2 に, 設定したロール基準の減面比 $\left(h_{\mathrm{r}} / h_{1}\right)$ とシートの減 面比 $\left(h_{2} / h_{1}\right)$ の関係，すなわち， ロール間隙之得られた シートの厚さの関係を示した， $\sigma$ が低い A 条件 $(\bigcirc)$ で は、ロール間隙を出た後のシートのスプリングバックに

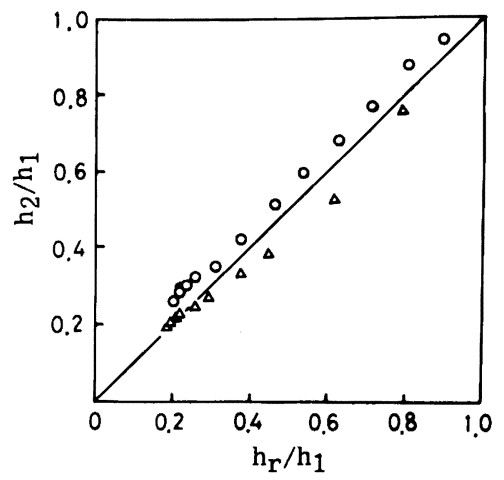

Fig. 2. Relationship between "roll standard" thickness reduction ratio $\left(h_{\mathrm{r}} / h_{1}\right)$ and thickness reduction ratio $\left(h_{2} / h_{1}\right)$. Front tension force: $\bigcirc, \sigma=65 \pm 5 \mathrm{kgf}$; $\triangle, \sigma=140 \pm 10 \mathrm{kgf}$.

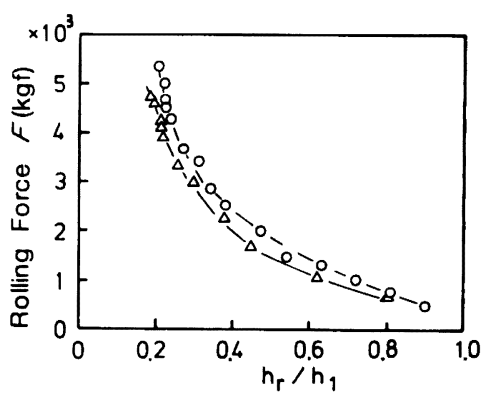

Fig. 3. Relationship between "roll standard" thickness reduction ratio $\left(h_{\mathrm{T}} / h_{1}\right)$ and rolling force $(F)$ : Symbols as in Fig. 2.

より, 压延シートの厚さ $\left(h_{2}\right)$ はロール間隙 $\left(h_{r}\right)$ よりも

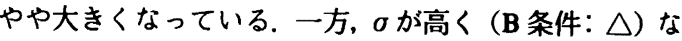
ると， $h_{2} \leqq h_{1}$ になっている． ロール通過直後の延伸あ加 わって， A 条件よりあシートの厚みが小さくなっている ことが分かる．また，ロール間隙が狭くなると， $h_{2} \leftrightharpoons h_{r}$ になっており，圧延の加工度を高めることで，寸法精度 のより良い压延が行われる。

Fig. 3 に, 圧下力 $(F)$ とロール間隙の設定值 $\left(h_{T} / h_{1}\right)$ の 関係を示した．ロール間隙を小さくすると，圧下力が急

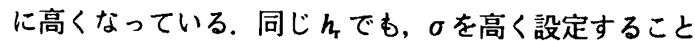
で $F$ はやや低下した。 なお，Fはロールの投影面積 $(S)$ 之平均圧延圧力 $(p)$ の関数である.

$$
\begin{aligned}
& F=p S \\
& S \leftrightharpoons w \sqrt{R\left(h_{1}-h_{\mathrm{T}}\right)}
\end{aligned}
$$

ここではシート幅, $w \leftrightharpoons 100 \mathrm{~mm}$, ロール半径, $R=50 \mathrm{~mm}$ である. 高い前方張力を付加することで, 平均圧延圧力 が低下することが分かる。 
ポリオキシメチレンの物性に及ぼす圧延の効果

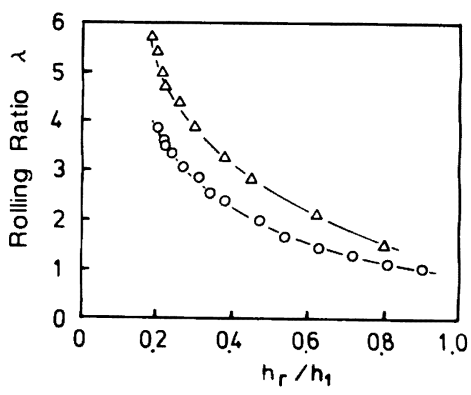

Fig. 4. Relationship between "roll standard" thickness reduction ratio $\left(h_{r} / h_{1}\right)$ and rolling ratio $\lambda$ : Symbols as in Fig. 2.

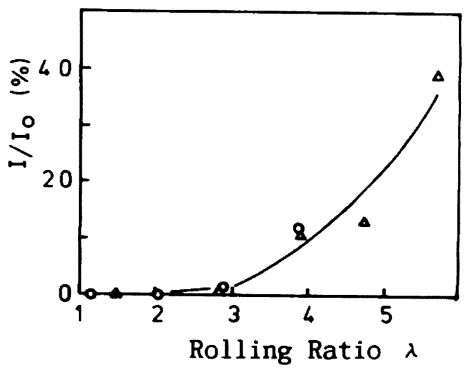

Fig. 5. Change of light transmittance at $550 \mathrm{~nm}$ of POM sheet with rolling ratio.

一般に，圧延において前方張力を付加しない場合に は, 圧延シートの厚みのみ減少し，幅の変化はほとんど 見られない.しかしここでは前方張力を付加したので， 圧延による試料シート幅の変化を調べた，圧延前後の試 料幅を $w_{1}, w_{2}$ としたとき, A 条件 $(\sigma=65 \pm 5 \mathrm{kgf})$ では $w_{2} / w_{1}=0.97 \sim 0.99$ の範囲であり, シート幅の隇少はわず かであった，一方, 前方張力の大きい B 条件 $(\sigma=140 \pm$ $10 \mathrm{kgf)}$ では， $w_{2} / w_{1}=0.91 \sim 0.94$ であった。 そこで，以降 の A， B 条件に共通の解析には，加工度として圧延倍率 (入) を使うこととした. 圧延前のシートの長さ $\left(L_{1}\right)$ と圧 延後のシートの長さ $\left(L_{2}\right)$ の比から, $\lambda$ を求めた. Fig. 4 $に h_{\mathrm{r}} / h_{1}$ と圧延倍率 $(\lambda)$ の関係を示した． 前方張力を高 く設定すると, 同じロール間隙 $h_{\mathrm{r}} / h_{1}$ に対しても, シー 卜幅がやや狭くなり，圧延倍率が高くなっている。

先に， ロールを用いたロール引抜加工法を POMにつ いても試みた ${ }^{12}$ が，そのときの延伸倍率は最高 21 倍で あり, 今回の圧延の場合よりも, 変形比がかなり高く なっており圧延の場合にも，圧延倍率をあげるために は，前方張力を高くすることが有効なことが分かる.

\section{2 圧延シートの外観}

POM 素材シートは白色不透明であり, 延伸加工に

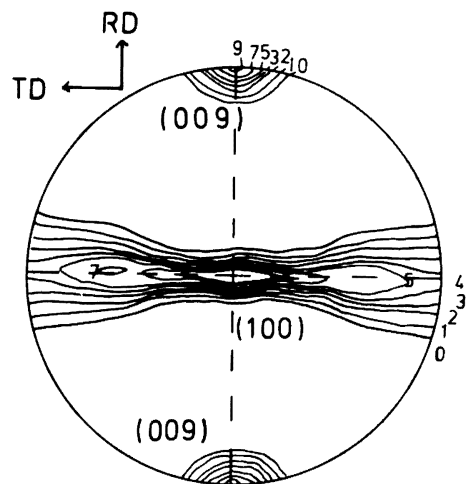

Fig. 6. 009 and 100 pole figure of rolled POM sheet: $\lambda=5.7$.

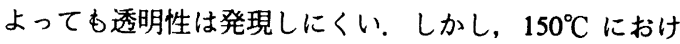
る圧延によって， シートは表面平滑で， かっ，透明に なった，圧延によって，ロール間での圧縮と，圧延方向 への分子鎖の伸長により，ミクロボイドの発生を㧕えな がら大変形が達成されていると考えられる.

圧延シートの透明性を評価するために，紫外可視分光 光度計を使って, $550 \mathrm{~nm}$ での透過率 $\left(I / I_{0}\right)$ を求めた.

Fig. 5 に透過率を入に対してプロットした. $\lambda$ が 3 を越 えると，光線透過率が急激に向上した。また， $\lambda$ が 3 を 越えると裸眼による観察でも透明感か増している，通常 の延伸加工では, POMの透明試料は得がたいが, 圧延 のように圧縮変形が主体となる变形では, 大変形の際の ボイドの発生が揤制されて，透明試料が得やすいことが 分かる.

\section{3 圧延シートの構造}

DSC 曲線のピーク温度から求めた融解温度は, 高圧 延倍率の試料で，素材シートに比へ，約 $4^{\circ} \mathrm{C}$ 上昇するも のの, さほど大きな変化は見られなかった。

密度も压延倍率が高くなるとやや低下するすのの, や はり大きな変化はなく, 密度から計算した結晶化度も 3 〜 4\% 程度低くなるにとどまった。しかしながら，前方 張力が高く（B 条件）, 圧延倍率がごく小さい場合 $(\lambda=$ 1.5〜2.8)には, 密度がかなり小さくなり, 伸長変形に対 する沁力が大きい場合には， ミクロボイドの発生を同わ せる. 先に, 延伸した POM の小角 X 線散乱に, ボイト 散乱に起因すると思われるストリークが生ずることを示 した ${ }^{\text {(8) }}$.

分子鎖の配向と選択配向を知るために, $\mathrm{X}$ 線極図形を 描いた. Fig. 6 には, 結晶 $c$ 軸の配向を表す $(009)$, 結晶 $a$ 軸の配向を表す (100) の X 線極図形の代表例として, 高圧延倍率 $(\lambda=5.70)$ の図形を示した。，各々の面につい て, 未配向試料のランタムレベルを 1 として等高線強度 


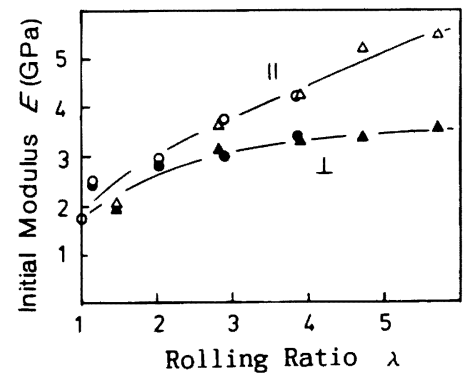

Fig. 7. Relationships between modulus of elasticity and rolling ratio: $\|$, rolling direction; $\perp$, transverse direction. Front tension force: $\bigcirc \bigcirc, \sigma=65 \pm 5 \mathrm{kgf}$; $\triangle \Delta, \sigma=140 \pm 10$ kgf.

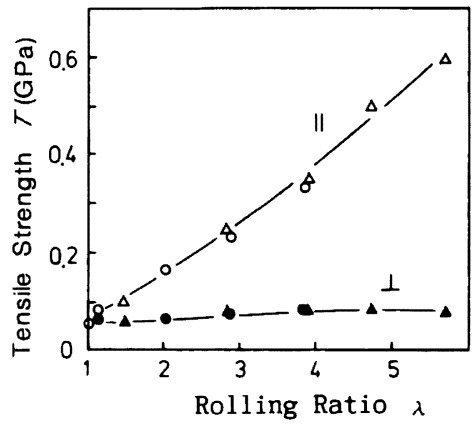

Fig. 8. Relationships between tensile strength and rolling ratio: Symbols as in Fig. 7.

で表し，009 極図形，100 極図形を一つの図に合成した。 (009) が RD 方向に収れんしており，結晶 $c$ 軸，すなわ 与分子鎖軸が压延方向によく配向している様子がよく分 かる. また, (100) がシート面に配向しており, ロール引 抜き加工法で得られた POM シートの場合と良く類似し ている ${ }^{12)}$

\section{4 弾性率と引張强さ}

分子銷の配向性を付与することで，物性を，特に，力 学物性を向上することができる。ここでも，圧延した POM の弾性率，引張強さはともに向上した，前方張力 $(\sigma)$ を高く設定した場合に，高い減面比が得られ，同じ 減面比のシートで比べる, 弾性率は $\sigma$ の高い条件の方 が高い値を示した. しかし，Fig.7に示すように, 圧延倍 率入で比較すると一連のデータを整理することができ ろ. 理延方向の弾性率 $E_{\| l}(O, \triangle)$ は $\sigma$ の大小によらず, $\lambda$ とともに単調に上昇している. POM の分子銷が完全 に配向したときの極限の弾性率として, 分子銷方向では $105 \mathrm{GPa}$ であることが報告されている ${ }^{19}$. この極限の弾 性率に比べると, 得られた値はまだかなり低い値にとど

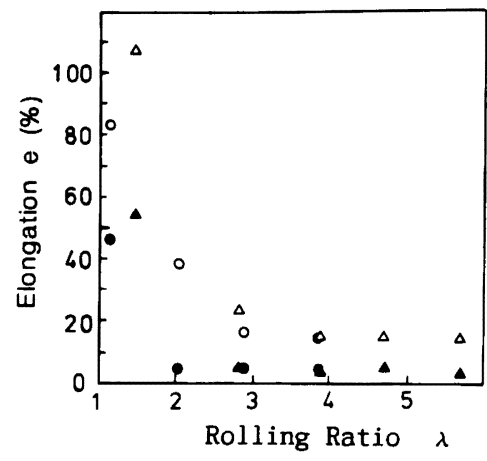

Fig. 9. Relationships between elongation at break and rolling ratio: Symbols as in Fig. 7.

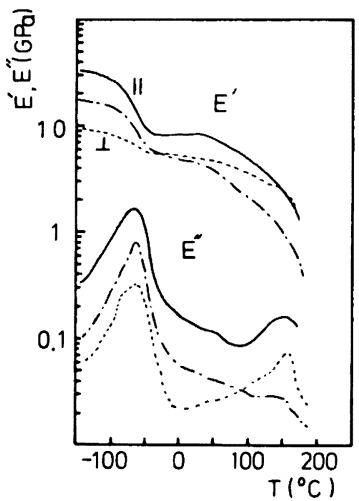

Fig. 10. Dynamic viscoelastic properties of rolled POM sheets $(\lambda=5.5)$ at $110 \mathrm{~Hz}:-\cdot-$, original sheet; - , rolling direction; ----, transverse direction.

まっている.

一方, 压延方向之直角方向，すなわち，シートの幅方 向の弾性率 $E_{\perp}(\boldsymbol{O}, \Delta)$ は $E_{l}$ より す低く，著しい異方性 を示している. しかし， $E_{\perp}$ あ素材シートの弾性率に比へ ると向上している. 圧延シートでは Fig. 6 に示したよう に, 結晶 $c$ 軸の配向之ともに, (100) 面配向が生じてお り,こうした構造が弾性率の変化に反映していると考え られる.

Fig. 8 には, $23^{\circ} \mathrm{C}$ での引張試験で求めた引張強さ $(T)$ を示した。弾性率と同様に，圧延倍率入に依存してい る. 压延方向の引張強さ $(O, \triangle)$ は $\lambda$ に対し, 直線的に 上昇している。 一方, シートの幅方向の引張強さ $(O$, A) は，素材シートの引張強さに比へ，ごくわずかしか 上昇しておらず，著しい異方性を示している。

Fig. 9 に, 破断時の伸び (e) を入に対してプロットし た. 素材シートの降状時の伸びは $13.6 \%$ であり, 圧延方 
向の破断伸びは $\lambda$ が極く小さいところで極大を示し， $\lambda$ が 3 以上になると一定になり，素材シートの降状時の伸 びと同程度になる。 シートの幅方向の伸びは $\lambda$ が 2 以上 で一定になり，圧延方向に比へ低い．

\section{5 動的粘弾性}

素材シート及び圧延シートの動的粘弾性の温度变化 $\left(-150^{\circ} \mathrm{C} \sim\right.$ 融解) を測定した. Fig. $10 \mathrm{~K}, 110 \mathrm{~Hz}$ で測定 した $\lambda=5.5$ の試料の動的弾性率 $E^{\prime}$ 之動的損失 $E^{\prime \prime}$ の圧 延方向及び幅方向の温度变化を示した，また，比較のた めに, 素材シートの $E^{\prime}, E^{\prime \prime}$ あ示した。

動的弾性率 $E^{\prime}$ は / とよで低温で著しい異方性を示し ている.しかし, 融解温度に近づくにしたがって，この 差は小さくなっている. また, 幅方向の $E^{\prime}(\perp: \cdots)$ は 低温で素材シートの $E^{\prime}(---)$ よりあ小さい値を示して いるが, $0^{\circ} \mathrm{C}$ 付近で逆転しており，素材シートの $E^{\prime} に$ に比 べ，高温での低下が少ない。

$-60^{\circ} \mathrm{C}$ 付近の $\gamma$ 分散の $E^{\prime \prime}$ ピークは非晶領域の主鎖 の分子運動によるものであるが，主鎖のコンホメーショ ンは9, らせん構造であり，主銷方向に大きな異方性を 示している. 先に, ロール引抜加工した POM シートに ついて，延伸比が高くなると $\gamma$ 分散の $\tan \delta$ ピークが高 くなり，さらに延伸比が高くなると再び $\tan \delta$ ピークが 小さくなることを報告した ${ }^{12}$. これは非晶領域の配向度 の向上と, さらに高い延伸比では非晶領域の分子運動が 配向により束縛されることで説明できた。ここで，圧延 シートの $\boldsymbol{E}_{\boldsymbol{\prime}}^{\prime}$ が $\gamma$ 分散温度以上で大きく低下する一方で, $\boldsymbol{E}_{\perp}^{\prime}$ があまり低下しないことから，この分散にはらせん 構造をもつ主鎖の伸縮運動加関係していると思われる。

$$
4 \text { まとめ }
$$

ポリオキシメチレンシートの圧延において，加工条 件, 発現する構造, 力学的性質の変化を検討した結果, 以下の結果を得た.

(1) 圧延により，透明性が発見し，ミクロボイドの発 生を抑えながら変形させることが可能である.

(2) 前方張力 (引取張力) を増すことで, スプリング バックを抑え高圧延倍率が得られる。

(3) 压延により, (100) 面配向之, 結晶 $c$ 軸（分子鎖 軸）の圧延方向への配向が生ずる.

(4) 圧延方向の弾性率は向上し, また，シート幅方向 についても改善された。

（5）引張強さは著しい異方性を示し, シート幅方向 については，わずかに変化するにとどまった。
(6) 動的弾性率の温度変化の測定から, 素材シート に比へ，融点近傍の温度まで，比較的高い弾性率を保持 できることが分かった.

以上の結果, 弾性率, 強度ともに, 圧延時の前方張力 （引取張力）の付加が有効であることを示すことができ

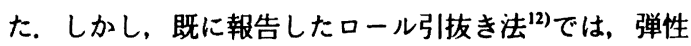
率 $25 \mathrm{GPa}$, 引張強さ $1.5 \mathrm{GPa}$ が得られており, 圧延では まだ低いレベルにある．また，圧延加工では幅方向の引 張強さがほとんど改善されない，今後，加工法としての 改善が検討課題となる.さらに検討を進めたい。

\section{文献}

1) A. G. Gibson and I. M. Ward, J. Polym. Sci., Polym. Phys. Ed., 16, 2015 (1978).

2) K. Nakayama and H. Kanetsuna, J. Mater. Sci, 10, 1105 (1975).

3) W. G. Perkins, N. J. Capiati, and R. S. Porter, Polym. Eng. Sci., 16, 200 (1976).

4) A. G. Gibson and I. M. Ward, Polym. Eng. Sci., 20, 1229 (1980).

5) Z. W. Wilchinsly, SPE J., 22, 46 (1966).

6) V. J. Dhingra, J. E. Spruiell, and E. S. Clark, Polym. Eng. Sci., 21, 1063 (1981).

7) D. M. Bigg, E. G. Smith, M. M. Epstein, and R. J. Fiorentino, Polym. Eng. Sci., 22, 27 (1982).

8) D. M. Gezovich and P. H. Geil, J. Mater. Sci., 6, 509 (1971).

9) S. Bahadur, Polym. J., 7, 613 (1975).

10）海藤 彰, 中山和郎，金綱久明，高分子論文集，42, 231 (1985).

11) A. Kaito, K. Nakayama, and H. Kanetsuna, J. Appl. Polym. Sci., 30, 1241 (1985).

12) A. Kaito, K. Nakayama, and H. Kanetsuna, J. Appl. Polym. Sci., 32, 3499 (1986).

13) P. E. Burke, G. C. Weatherly, and R. T. Woodhams, Polym. Eng. Sci., 27, 518 (1987).

14) M. P. Laughner and I. R. Harrison, J. Appl. Polym. Sci., 33, 2955 (1987).

15）中山和郎, 玉村日出隆, 浅沢英夫, 金綱久明, 塑性と加工, 21, 1096 (1980).

16）中山和郎，望月政夫，金綱久明，塑性と加工， 25，233 (1984).

17) A. Kaito, K.Nakayama, and H. Kanetsuna, J. Appl. Polym. Sci., 28, 1207 (1983).

18）中山和郎，金網久明，佐竹一良，冲 泰，塑性之加工, 15, 744 (1974).

19) B. Brew, J. Clements, G. R. Davies, R. Jakeway, and I. M. Ward, J. Polym. Sci., Polym. Phys. Ed., 17, 351 (1979). 
Effect of Hot Rolling on the Properties of Polyoxymethylene Sheets

Kazuo NAKAYAMA*1 and Akira KaIto*1

${ }^{* 1}$ Research Institute for Polymers and Textiles (1-1-4, Higashi, Tsukuba, Ibaraki 305, Japan)

The rolling of commercial extruded sheets of polyoxymethylene (POM) was carried out at the roll temperature of $150^{\circ} \mathrm{C}$. The action of a tensile force was applied to the product during the hot rolling. A stable rolling process has been conducted experimentally. The relationships between mechanical properties and rolling conditions were studied. The tensile force applied to the product affected both the rolling force and the rolling ratio. The main effect of increasing the rolling ratio was to increase the tensile modulus and the strength of the rolled sheet. A striking feature of specimens obtained at high rolling ratio is their high degree of transparency.

KEY WORDS Rolling / Polyoxymethylene / Mechanical Properties / Preferred Orientation / Dynamic Viscoelastic Properties /

(Received April 6, 1991: Accepted April 19, 1991)

[Kobunshi Ronbunshu, 48(11), 679-684 (1991)] 